\title{
NOTES AND NEW DATA ON THE DISTRIBUTION OF A NON-NATIVE OLIGOCHAETE: BRANCHIURA SOWERBYI (BEDDARD, 1892) IN CROATIA
}

\author{
Natalija Vučković ${ }^{*}$, Ivana Pozojević ${ }^{1}$, Mladen Kerovec ${ }^{1}$, \\ Valentina Dorić $^{2}$ \& Zlatko Mihaljević ${ }^{1}$
}

\author{
${ }^{1}$ Department of Biology - Zoology, Faculty of Science, University of Zagreb, Rooseveltov trg 6, \\ 10000 Zagreb, Croatia \\ ${ }^{2}$ Eko monitoring, Kučanska ul. 15, 42000 Varaždin, Croatia
}

Vučković, N., Pozojević, I., Kerovec, M., Dorić, V. \& Mihaljević, Z.: Notes and new data on the distribution of a non-native oligochaete: Branchiura sowerbyi (Beddard, 1892) in Croatia. Nat. Croat., Vol. 28, No. 2., 455-462, Zagreb, 2019.

The freshwater oligochaete Branchiura sowerbyi is indigenous to southeast Asia, but can be found inhabiting most of Europe. This tubificid was even described for the first time outside of its natural area of occurrence: in the garden of the Royal Botanic Society in London. It has spread over all continents except Antarctica, and in Europe it has been found in 23 countries. The presence of this non-native species may affect other species' relationships in the benthic community and thus have substantial effects on food webs of aquatic ecosystems. Our goal was to present the first comprehensive overview of the distribution of this potentially invasive species in Croatia as a basis for the future monitoring of the species distribution. In Croatia, B. sowerbyi was found for the first time in 1954 in Varaždin's thermal stream and the following year in the lake of the Botanical garden, Faculty of Science, University of Zagreb. To date, B. sowerbyi individuals were found on 64 different sites in Croatia, mostly occupying the Pannonian Lowland Ecoregion (ER 11) with only two findings in the Dinaric Western Balkan Ecoregion (ER 5).

Key words: invasive species, tubificid distribution, Dinaric Western Balkan Ecoregion, Pannonian Lowland Ecoregion

Vučković, N., Pozojević, I., Kerovec, M., Dorić, V. \& Mihaljević, Z.: Pregled istraživanja i novi nalazi rasprostranjenosti alohtonog maločetinaša Branchiura sowerbyi u Hrvatskoj. Nat. Croat., Vol. 28, No. 2., 455-462, Zagreb, 2019.

Prirodni areal rasprostiranja vrste Branchiura sowerbyi je jugoistočna Azija, no ovaj se maločetinaš može pronaći u slatkovodnim ekosustavima diljem Europe. Čak je i prvi opis ove vrste tubificida bio izvan njegovog prirodnog areala rasprostiranja, točnije u botaničkom vrtu „Royal Botanic Society“ u Londonu. Ova vrsta danas je prisutna na svim kontinentima osim Antartike, a u Europi je zabilježena u 23 zemlje. Prisustvo ove alohtone vrste može imati još neutvrđene implikacije na zajednice slatkovodnih makroskopskih beskralježnjaka, kao i na funkcioniranje hranidbenih mreža unutar ovih zajednica. Cilj ovog rada bio je izraditi sveobuhvatan pregled distribucije ove vrste na području Hrvatske kao bazu za buduće nadziranje širenja te vrste. U Hrvatskoj je vrsta B. sowerbyi nađena prvi put 1954. godine u termalnom potoku u Varaždinu, a već sljedeće godine pronađena je u Botaničkom vrtu Sveučilišta u Zagrebu. Dosad je vrsta zabilježena na 64 različite lokacije na području Hrvatske, većinom u Panonskoj ekoregiji (ER 11), dok je u Dinaridskoj ekoregiji (ER 5) dosad zabilježena na samo dvije lokacije.

Ključne riječi: invazivna vrsta, rasprostranjenost tubificida, Dinaridska ekoregija, Panonska ekoregija

\footnotetext{
* corresponding author: natalija.vuckovic@biol.pmf.hr
} 


\section{INTRODUCTION}

The majority of freshwater ecosystems in Europe are under some form of anthropogenic impact: water drainage, dam construction, river flow alternation and many others (WARD et al., 1999). Alongside all these negative environmental influences, there is also the influence of alien invasive species introduction (ELTON, 1958). The transport of people and goods increased in the last century, and so did the transfer of non-indigenous animals, plants and microorganisms (BRYAN, 1996). Alien species may change both the taxonomic and functional composition of the community and even become the dominant taxon or functional entity (VERMEIJ, 1996). Nevertheless, some authors suggest that "invasive species denialism" is gaining more followers in the scientific community (RUSSELL \& BLACKBURN, 2017a, b). Regardless of the denialism theory, in practice the invasions truly are most often revealed too late, when they have already grown to a very large scale, and as such, are difficult to suppress.

These, intentionally or unintentionally introduced, species are allochthonous or non-native and they could become invasive species if the conditions are favorable (Gollasch \& Nehring, 2006). Alien species who find themselves in a new area often do not have natural predators, so they have the possibility to become great competitors (PYšÉ \& PYšEK, 1995; MACDougall et al., 2009). One of the most important scientific tasks is to predict the outcomes of the introduction of a particular species and the possible impact on ecosystems that are housing or might house the non-native species. This can be done only if comprehensive and detailed data is kept on the distribution and dispersal rates of the alien species.

One of the potentially invasive species is a widespread tubificid oligochaete Branchiura sowerbyi (BEDDARD, 1892) native to Southeast Asia (Mills et al., 1993). $B$. sowerbyi can be typically found in warmer freshwaters that are rich in organic matter and with flow rates of less than $0.5 \mathrm{~ms}^{-1}$ (PAunovic et al., 2005). With high distributional spreading rates and high breeding rates, $B$. sowerbyi has a great invasive potential which could be triggered by various anthropogenic instabilities in freshwater ecosystems such as temperature, elevation or habitat degradation (CARrol \& Dorris, 1972; Nehring 2002). The tubificid was described for the first time by BEDDARD (1892) in the garden of the Royal Botanic Society in London. In Southeast Asia, it was first identified by BRINKHURST in 1969. It is spread over all continents except Antarctica. In Europe, it has been found in 23 countries (www. fauna-eu.org/). It is assumed that $B$. sowerbyi has been spread by ornamental aquatic plant transport and by importing fish for aquacultural purposes (PAunovic et al., 2005). B. sowerbyi can reproduce both sexually and asexually (by fragmentation) and at temperatures between 21 and $29^{\circ} \mathrm{C}$ they exhibit great reproductive potential, ascending at $25^{\circ} \mathrm{C}$ (Aston et al., 1982). Their growth and reproduction are influenced by the amount of organic matter present in freshwater substrates (GEorgieva et al., 2012). Because of its great reproduction rates and size (it can grow to $185 \mathrm{~mm}$ ) $B$. sowerbyi is frequently used as food in fish farming facilities. On the other hand, recent research has shown that $B$. sowerbyi can serve as a host for a microscopic cluster of Myxozoa, which causes various diseases in fish used in aquaculture (ZHAo et al., 2016) leading to both ecologic and economic damage (Hedrick, 1998). 
The presence of this species may affect other species' relationships in the benthic community and thus have a substantial effect on food webs of aquatic ecosystems (Paunovic et al., 2005). Due to its size and easy handling, this species is also used in ecotoxicological research to estimate the level of contamination of river and lake sediments with various pollutants (CAsEllato et al., 1992).

In Croatia, B. sowerbyi was found for the first time in 1954 in Varaždin's thermal stream (MATONIČKIN, 1957) and the following year in the lake of the Botanical garden, Faculty of Science, University of Zagreb (Devide, 1956). B. sowerbyi was later found in the artificial lake Jarun near Zagreb (Kerovec et al. 1989), the lower course of the Krapina River north of Zagreb and in the hydroelectric power plant reservoir on the Drava River near Varaždin (Minaljević et al., 2007; Kerovec et al., 2016). Since the beginning of $21^{\text {st }}$ century, intensive monitoring and freshwater research according EU Water framework directive requirements were conducted on all types of water bodies in Croatia, yielding new data and evidence on the growing distribution of this species. Our goal was to present the first comprehensive overview of the distribution of this potentially invasive species in Croatia.

\section{MATERIAL AND METHODS}

\section{Study area}

The territory of Croatia spreads across two ecoregions: the Dinaric Western Balkan Ecoregion (ER 5) and the Pannonian Lowland Ecoregion (ER 11) (ILLIEs, 1978). The ER 5 is characterized by a range of different climates: temperate-humid to humid-boreal climate, with warm summers in the mountainous eastern part of ER 5, whereas the western (Mediterranean) part is in most part characterized by Mediterranean climate but in some areas has a temperate humid climate, both with dry hot summers. ER 11 is in most part characterized by temperate-humid climate (ŠEGOTA \& FILIPČIĆ, 2003). Research in both Ecoregions has been evenly conducted within the investigated period.

\section{Data collection}

This paper represents a comprehensive overview of the presence of $B$. sowerbyi in Croatia, incorporating literary data with unpublished research data. All new records are the result of multiannual (1987 - 2018) research and monitoring projects of the Department of Biology, Division of Zoology, Faculty of Science, University of Zagreb, Croatia. All collected oligochaete specimens are deposited in this institution.

B. sowerbyi individuals were identified using BRINKHURST (1986) and TIMm (2009).

\section{RESULTS AND DISCUSSION}

To date, B. sowerbyi individuals with their distinctive finger-like posterior gills (Fig. 1) were found on 64 different sites in Croatia (Tab. 1). Although all research did not evaluate abundance, it is important to note that $B$. sowerbyi abundance ratios were found to be very high in some artificial or anthropogenicaly altered freshwater 
habitats. A study conducted on reservoirs in 2016 showed that $B$. sowerbyi abundances might make up as much as half of the total macroinvertebrate abundance in these lentic habitats. This was the case in Gravel pit Novo Čiče (site 46) where $51 \%$ of all macroinvertebrate individuals were $B$. sowerbyi. A study conducted on channels and channelized lotic habitats in 2018 showed abundance percentages of B. sowerbyi reaching up to $42 \%$ in Sutla River (Donje Brezno) (site 62).

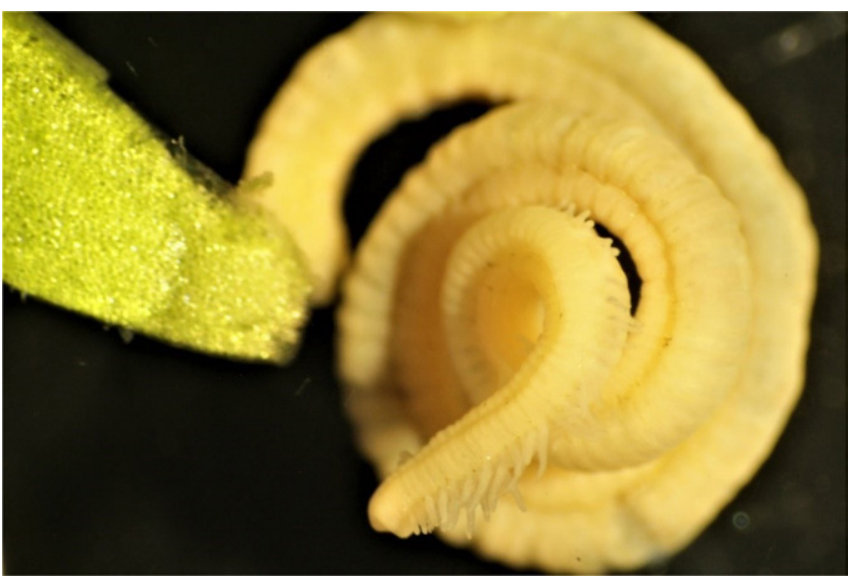

Fig. 1. Finger-like gills on posterior end of a $B$. sowerby $i$ specimen found in Bednja River (Site 43).

Tab. 1. General information on sites of B. sowerbyi findings in Croatia.

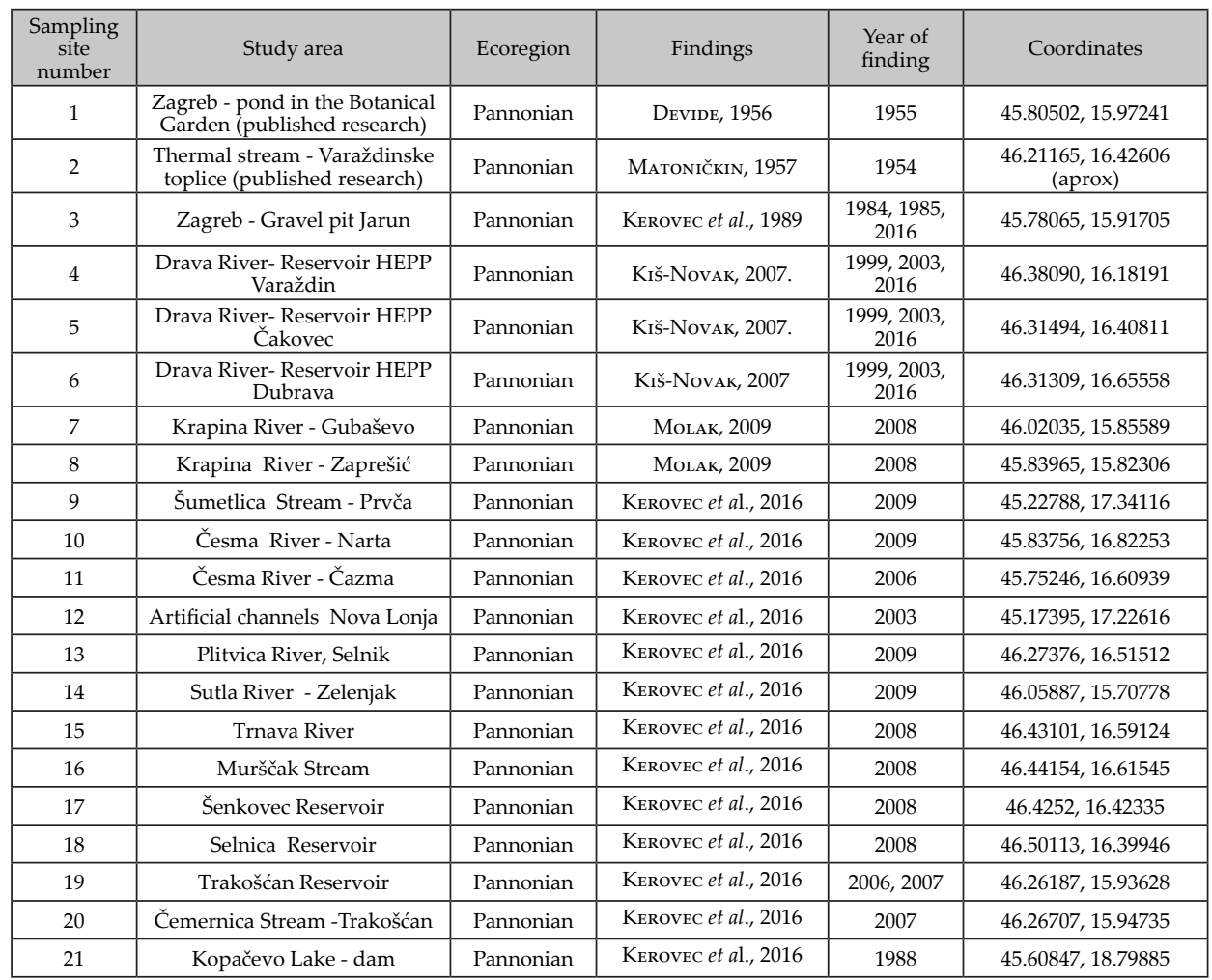




\begin{tabular}{|c|c|c|c|c|c|}
\hline 22 & Old River Drava - Osijek & Pannonian & Kerovec et al., 2016 & 1988. & $45.54945,18.75563$ \\
\hline 23 & Drava River - Osijek (Bilje) & Pannonian & Kerovec et al., 2016 & 1988 & $45.591257,18.734397$ \\
\hline 24 & Drava River - D. Miholjac & Pannonian & Kerovec et al., 2016 & 2009 & $45.77507,18.17291$ \\
\hline 25 & Drava River - Botovo & Pannonian & Kerovec et al., 2016 & 2009 & $46.23362,16.94265$ \\
\hline 26 & $\begin{array}{c}\text { Drava River - Old river channel } \\
\text { HEPP Dubrava }\end{array}$ & Pannonian & $\begin{array}{c}\text { KIš-NovaK, 2007; } \\
\text { MinaljEvić et al., } 2007\end{array}$ & 2002 & $46.31736,16.74408$ \\
\hline 27 & $\begin{array}{c}\text { Drava River - Old river channel } \\
\text { HEPP Cakovec }\end{array}$ & Pannonian & Kerovec et al., 2016 & $\begin{array}{l}\text { 2010, 2011, } \\
2012\end{array}$ & $46.30759,16.52381$ \\
\hline 28 & $\begin{array}{l}\text { Drava River - Old river channel } \\
\text { HEPP Varaždin }\end{array}$ & Pannonian & Kerovec et al., 2016 & $\begin{array}{c}2002,2004 \\
2006,2008, \\
2012\end{array}$ & $46.37636,16.19298$ \\
\hline 29 & Sava River - Račinovci & Pannonian & $\begin{array}{c}\text { Kerovec \& Kerovec, } \\
2014 \\
\end{array}$ & 2009. & $44.85092,18.96052$ \\
\hline 30 & Sava River - Gunja & Pannonian & $\begin{array}{c}\text { Kerovec \& Kerovec, } \\
2014 \\
\end{array}$ & 2004,2007 & $44.88089,18.81477$ \\
\hline 31 & Sava River - Stara Gradiška & Pannonian & $\begin{array}{c}\text { Kerovec \& Kerovec, } \\
2014 \\
\end{array}$ & 2004,2007 & $45.14844,17.24841$ \\
\hline 32 & Crna Mlaka - Fish Pond & Pannonian & Kerovec et al., 2016 & 1987 & $45.61595,15.73151$ \\
\hline 33 & Kraljevec Stream - Zagreb & Pannonian & Kerovec et al., 2016 & 2003 & $45.88000,15.94111$ \\
\hline 34 & Maksimir Lake II - Zagreb & Pannonian & Keroveve et al., 2016 & 2003 & $45.82289,16.02131$ \\
\hline 35 & Maksimir Lake III - Zagreb & Pannonian & Kerovec et al., 2016 & 2003 & $45.82541,16.01830$ \\
\hline 36 & Maksimir Lake V - Zagreb & Pannonian & Kerovec et al., 2016 & 2003 & 45.8328016 .02453 \\
\hline 37 & $\begin{array}{c}\text { Bliznec Stream - Zagreb } \\
\text { (Maksimir) }\end{array}$ & Pannonian & Kerovec et al., 2016 & 2003 & $45.83585,16.02702$ \\
\hline 38 & Radonja River - Vojnić & Pannonian & Kerovec et al., 2016 & 2006 & $45.32731,15.69702$ \\
\hline 39 & $\begin{array}{c}\text { Turpinjska River - Grabovac } \\
\text { Krnjacki }\end{array}$ & Pannonian & Kerovec et al., 2016 & 2006 & $45.34193,15.61417$ \\
\hline 40 & Mrežnica River - Karlovac & Pannonian & Kerovec et al., 2016 & 2006 & $45.46533,15.53788$ \\
\hline 41 & Botonega reservoir (Istria) & Dinaric & Kerovec et al., 2016 & 2012 & $45.32562,13.92199$ \\
\hline 42 & Dobra River - Jarče Polje & Dinaric & New record & 2006 & $45.45629,15.41299$ \\
\hline 43 & Bednja River-Lepoglava & Pannonian & New record & 2015 & $46.20722,16.04055$ \\
\hline 44 & Bednja River-Ludbreg & Pannonian & New record & 2015 & $46.25694,16.63583$ \\
\hline 45 & Gravel pit Rakitje & Pannonian & New record & 2016 & $45.78965,15.84373$ \\
\hline 46 & Gravel pit Novo Čiče & Pannonian & New record & 2016 & $45.71184,16.10331$ \\
\hline 47 & Borovik reservoir & Pannonian & New record & 2016 & $45.39164,18.18720$ \\
\hline 48 & Jošava reservoir & Pannonian & New record & 2016 & $45.32278,18.45258$ \\
\hline 49 & Lapovac II reservoir & Pannonian & New record & 2016 & $45.48027,18.11297$ \\
\hline 50 & Pakra reservoir & Pannonian & New record & 2016 & $45.43810,16.89887$ \\
\hline 51 & Popovac reservoir & Pannonian & New record & 2016 & $45.63776,16.87407$ \\
\hline 52 & Sakadaš Lake & Pannonian & New record & 2016 & $45.60828,18.80041$ \\
\hline 53 & Grabova reservoir & Pannonian & New record & 2016 & $45.27137,19.07371$ \\
\hline 54 & Gravel pit Koprivnica & Pannonian & New record & 2016 & $46.23605,16.90363$ \\
\hline 55 & Glogovnica-Donji Lipovčani & Pannonian & New record & 2018 & $45.75602,16.53428$ \\
\hline 56 & Pakra-Janja Lipa & Pannonian & New record & 2018 & $45.44702,17.01271$ \\
\hline 57 & Ilova-Veliki Zdenci & Pannonian & New record & 2018 & $45.66638,17.12173$ \\
\hline 58 & Drava Ledine Molvanske & Pannonian & New record & 2018 & $46.12931,17.06687$ \\
\hline 59 & Drava-Storgač & Pannonian & New record & 2018 & $46.05062,17.25237$ \\
\hline 60 & Drava-Gat, Petrovo selo & Pannonian & New record & 2018 & $45.72774,18.31975$ \\
\hline 61 & Črnomerec, Srednjaci & Pannonian & New record & 2018 & $45.79151,15.93752$ \\
\hline 62 & Sutla River-Donje Brezno & Pannonian & New record & 2018 & $46.18220,15.63790$ \\
\hline 63 & Kapinci channel, near Drava & Pannonian & New record & 2018 & $45.80835,17.70868$ \\
\hline 64 & Sava River-Slavonski Brod & Pannonian & New record & 2018 & $45.15221,18.00074$ \\
\hline
\end{tabular}


In general, B. sowerbyi did not extend to the area of the Dinaric Ecoregion (ER 5, Fig. 2), with the exception of a reservoir located in Istria (Butoniga, site 41) which is part of Adriatic basin and a river located near the border of the two ecoregions (Dobra River, site 42) which is part of Black sea basin. ER 5 has some parts that are of similar climate to ER 11 (temperate-humid climate) and even parts that have warmer Mediterranean climate that would be more suitable for the southeast-Asian species. Nevertheless, populations of $B$. sowerbyi were not noted in this warmer Mediterranean climate. Most rivers and lakes of the ER 5 are located on karstic terrain and rich in calcium carbonate (in both sediment and dissolved in water). The Botonega reservoir is an exception: in the upper part of its basin geological layers have flysch and alluvial deposits prone to erosion, which is more characteristic for reservoirs of ER 11 rather than ER 5 (Žı et al., 2010). Further research is needed to assess species' preferences to specific environmental characteristics of each ecoregion.

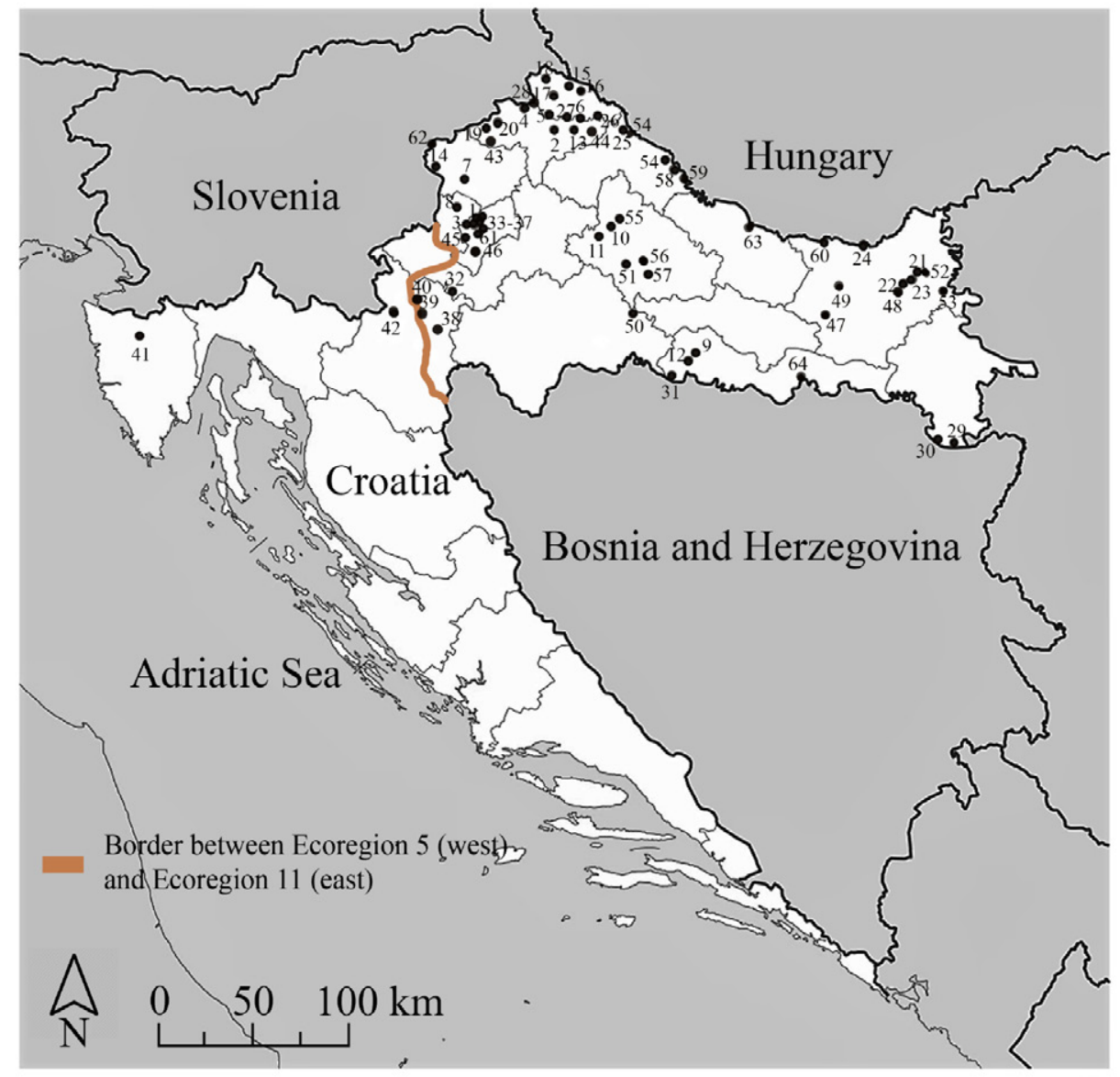

Fig. 2. Distribution of Branchiura sowerbyi in Croatia. Location numbers are presented in Tab. 1. 
B. sowerbyi is seemingly not the dominant oligochaete species present in Croatian water bodies in general, although its abundances appear to proliferate in artificial or heavily modified water bodies of ER 11. This shift in dominance within oligochaete assemblages may prove to occur with hydromorphological alternations or even as a result of climate change. Continuous research and monitoring are needed to determine how this species affects biodiversity and freshwater invertebrate community dynamics and if its presence can indicate ecological degradation in the ecosystems.

\section{ACKNOWLEDGEMENTS}

Iva Vidaković is gratefully acknowledged for providing oligochaete samples of the Bednja River. The research on heavily modified water bodies of Croatia has been intensified over the last three years complying to the demands of the WFD. Two projects on these types of water bodies funded by Hrvatske vode, provided us with much needed data on the dispersion of Branchiura sowerbyi in Croatia: Development of a System for Classifying the Ecological Potential for artificial and heavily modified surface water bodies - Part 1 and 2 (Contract class: 325-01/1610/22 Docket No.: 374-1- 2-16-8 Contract No.: 10-034/16).

Received September 10, 2019

\section{REFERENCES}

Aston, A. R. J., Sadler, K. \& Milner, A. G. P., 1982: The effects of temperature on the culture Branchiura sowerbyi (Oligochaeta, Tubificidae) on activated sludge. Aquaculture 29 (1-2), 137-145.

BeDdARD, F. E., 1892: A new branchiate Oligochate (Branchiura sowerbyi). Quarterly Journal of Microscopical Science 33, 325 - 341.

Brinkhurst, R. O., 1969: Aquactic Oligochaeta of the Azores and Madeira. Boletim do Museu Municipal do Funchal 23, 46 - 48.

BrinkHurst, R.O., 1986. Guide to the freshwater aquatic microdrile oligochaetes of North America. Department of Fisheries and Oceans, Ottawa, 1 - 529.

Bryan, R. T., 1996: Alien species and emerging infectious diseases: Past lessons and future applications. In: Sandlund G. T., Schel P. J., Viken A., (eds.), Proceedings of the Norway UN Conference on Alien Species. Norwegian Institute for Nature Research, Trondheim, Norway. p. 74-80.

Carroll, J. H. \& Dorris, T. C., 1972: The life history of Branchiura sowerbyi. American Midland Naturalist 87, 413-422.

Casellato, S., Aiello, R., Negrisolo, P. A. \& Seno M., 1992: Long-term experiment on Branchiura sowerbyi Beddard (Oligochaeta, Tubificidae) using sediment treated with LAS (Linear Alkylbenzene Sulphonate). Hydrobiologia 232, 169-173.

Devide, Z., 1956: Branchiura sowerbyi u jezeru botaničke bašte u Zagrebu. Biol. Vestnik 5, 76-78.

Elton, C. S., 1958: The ecology of invasions by animals and plants. Methuen, London. p. 159.

Georgieva, G., Varadinova E. \& Uzunov Y., 2012: Distribution of non indigenous tubificid worm Branchiura sowerbyi (Beddard, 1892) in Bulgaria. Journal of Bioscience and Biotechnology, SE/ ONLINE: 105-113.

Gollasch, S. \& Nehring, S., 2006: National checklist for aquatic alien species in Germany. Aquatic Invasions 1, 245-269.

Hedrick, R. P., 1998: Relationships of the host, pathogen and environment: Implications for diseases of cultured and wild fish populations. Journal of Aquatic Animal Health 10, 107-111. 
ILLIES, J., 1978: Limnofauna Europaea. A Checklist of the Animals Inhabiting European Inland Waters, with an Account of their Distribution and Ecology. 2nd Edition. Gustav Fischer Verlag, Stuttgart. p. 552.

Kerovec, M., TAvČar, V. \& Meštrov, M., 1989: Macrozoobenthos as an indicator of the level of the trophy and saprobity of lake Jarun. Acta Hydrochimica et Hydrobiologica 17 (1), 37-45.

Kerovec, M. \& Kerovec, M., 2014: Oligochaeta and Polychaeta fauna of the Croatian part of the Sava River. Natura Croatica, 23, 335-348.

Kerovec, M., Kerovec, M. \& Brigić, A., 2016: Croatian freshwater oligochaetes: species diversity, distribution and relationship to surrounding countries. Zootaxa, 4193 (1): 073-101.

KIš-NovaK, D., 2007: Makrozoobentos kao pokazatelj kakvoće vode akumulacija na rijeci Dravi. Magistarski rad, Sveučilište u Zagrebu. Masters thesis, University of Zagreb, Faculty of Science. In Croatian.

MacDougall, A. S., Gilbert, B. \& Levine, J., 2009: Plant invasions and the niche. - Journal of Ecology., 97: 609-615.

MatoničKIN, I., 1957: Ekološka istraživanja faune termalnih voda Hrvatskog Zagorja. Jugoslavenska Akademija znanosti i umjetnosti RAD 312, 139-206. [Ecological research of thermal waters in Croatian Zagorje] In Croatian.

Mihaljević, Z., Kerovec, M. \& Ternjej, I., 2007: Maločetinaši (Oligochaeta) kao pokazatelji trofije akumulacija na rijeci Dravi. In: GeREš, D. (Ed.), Zbornik radova 4. Hrvatska konferencija o vodama: Hrvatske vode i Europska unija-izazovi i mogućnosti. Sveučilišna tiskara, Zagreb, pp. 163-169. In Croatian.

Mills, E. L., Leach, J. H., Carlton, J. T. \& Secor, C. L., 1993: Exotic species in the Great Lakes: a history of biotic crises and anthropogenic introductions. Journal of Great Lakes Research 19 (1), 1-54.

MolAK, Z., 2009: Makrozoobentos kao pokazatelj sezonskih i prostornih razlika u kakvoći vode rječica Krapine i Krapinice. Magistarski rad. Prirodoslovno-matematički fakultet, Sveučilište u Zagrebu. Masters thesis, University of Zagreb, Faculty of Science. In Croatian.

Nehring, S., 2002: Biological invasions into German waters: an evaluation of the importance of different human-mediated vectors for nonindigenous macrozoobenthic species. In: LеррёкоsкI, E., Gollasch, S., Olenin, S. (Eds.) Invasive aquatic species of Europe: Distribution, impacts and management. Kluwer Academic: Dordrecht.

Paunovic, M., Miljanovic, B., Simic, V., Cakic, P., Djikanovic, V., Jakovcev-Todorovic, D., Stojanovic, B. \& Veljкovic, A., 2005: Distribution of non-indigenous tubificid worm Branchiura sowerbyi (Beddard, 1892) in Serbia. Biotechnology \& Biotechnological Equipment 3, 91-97.

PYšEK, P. \& PY̌̌EK, A., 1995: Invasion by Heracleum mantegazzianum in different habitats in the Czech Republic. Journal of Vegetation Science 6, 711-718.

Russell, J. C. \& Blackburn, T. M., 2017a: The Rise of Invasive Species Denialism. Trends in Ecology Evolution 32, 3-6.

Russell, J. C. \& Blackburn, T. M., 2017b: Invasive Alien Species: Denialism, Disagreement, Definitions, and Dialogue. Trends in Ecology \& Evolution 32, 312-314.

Šegota, T. \& Filıpčrć, A., 2003: Köppenova podjela klima i hrvatsko nazivlje. Geoadria 8 (1), 17-37 (In Croatian).

Tiмm, T., 2009: A Guide to the Freshwater Oligochaeta and Polychaeta of Northern and Central Europe. Lauterbornia 66, 1-235.

VermeIJ, G. J., 1996: An agenda for invasion biology. Biological Conservation 78, 3-9.

WARD, J. V., Tockner, K. \& SCHIEMER, F., 1999: Biodiversity of floodplain river ecosystems: Ecotones and connectivity. River Research and Applications 15, 125-139.

www.https://fauna-eu.org (Accessed on October 12019 ).

Zhao, D., Borkhanuddin, M. H., Wang, W., Liu, Y., Cech, G., Zhai, Y., \& SzéKely, C., 2016: The life cycle of Thelohanellus kitauei (Myxozoa: Myxosporea) infecting common carp (Cyprinus carpio) involves aurantiactinomyxon in Branchiura sowerbyi. Parasitology Research 115 (11), 4317-4325.

Žic, E., Ožanić, N. \& Vranješ M., 2010: Function of the Drainage-Retaining Botonega Channel in the Integrated Management of the Botonega Accumulation. Conference paper: Balowis 2010 At: Ohrid, Republic of Macedonia; DOI: 10.13140/2.1.1795.9682. 